\title{
Treatment of Sulfonated Azo Dye Reactive Red 198 by UV/H $\mathbf{H}_{2} \mathrm{O}_{2}$
}

\author{
Jefferson P. Ribeiro, ${ }^{1}$ Juliene T. Oliveira, ${ }^{2}$ André G. Oliveira, ${ }^{2}$ \\ Francisco W. Sousa, ${ }^{1}$ Eliezer F. Abdala Neto, ${ }^{1}$ Carla B. Vidal, ${ }^{1}$ Denis de Keukeleire, ${ }^{3}$ \\ André B. dos Santos, ${ }^{1}$ and Ronaldo F. Nascimento ${ }^{2}$ \\ ${ }^{1}$ Department of Hydraulic and Environmental Engineering, Federal University of Ceará, Rua do Contorno, S/N Campus do Pici, \\ Bloco 713, 60451-970 Fortaleza, CE, Brazil \\ ${ }^{2}$ Department of Analytical Chemistry and Physical Chemistry, Federal University of Ceará, Rua do Contorno, \\ Humberto Monte S/N Campus do Pici, Bloco 940, 60451-970 Fortaleza, CE, Brazil \\ ${ }^{3}$ Faculty of Pharmaceutical Sciences, Ghent University, Harelbekestraat 72, 9000 Ghent, Belgium
}

Correspondence should be addressed to Ronaldo F. Nascimento; ronaldo@ufc.br

Received 7 July 2014; Accepted 8 August 2014; Published 8 September 2014

Academic Editor: Vijay K. Thakur

Copyright (C) 2014 Jefferson P. Ribeiro et al. This is an open access article distributed under the Creative Commons Attribution License, which permits unrestricted use, distribution, and reproduction in any medium, provided the original work is properly cited.

$\mathrm{UV} / \mathrm{H}_{2} \mathrm{O}_{2}$ system was tested on the color removal of sulfonated azo dye Reactive Red 198 (RR), which is widely used in textile process. The effects of hydrogen peroxide concentration, temperature, $\mathrm{pH}$, and the in-line addition of hydrogen peroxide on high color and chemical oxygen demand (COD) removals were investigated. The kinetic of dye decolorization was also determined. The results showed that $2 \% \mathrm{H}_{2} \mathrm{O}_{2}$ decreased the process efficiency, while $1 \% \mathrm{H}_{2} \mathrm{O}_{2}$ solution led to a better performance of the system. Despite the fact that the $\mathrm{pH}$ increase had small effect on color removal, it affects positively COD removals. The same behavior was found for temperature increase. A high temperature resulted in a slight decrease in color removal and a sharp decrease for COD removal. In addition the $\mathrm{H}_{2} \mathrm{O}_{2}$ in-line provided a small improvement in both color and COD removals. UV/1\% $\mathrm{H}_{2} \mathrm{O}_{2}$ treatment was the most efficient, the good performance was linked to higher amount of hydroxyl radicals formed.

\section{Introduction}

The contamination of natural waters has been identified as one of the biggest problems in modern society. The textile industry has been a particular focus because it is associated with the use of inputs (dyes, detergents, and fabric softeners) and the generation of large volumes of effluent due to the overuse of water $[1,2]$.

Textile effluents are often highly colored due to the presence of dyes that are not fixed onto the fiber during the dyeing process, and these effluents contain large amounts of suspended solids. In addition, textile effluents have highly fluctuating $\mathrm{pH}$ values, elevated temperatures, high chemical oxygen demands (CODs), and considerable concentrations of toxic metal ions $(\mathrm{Cr}, \mathrm{Ni}$, and $\mathrm{Cu})$ [3]. It has been estimated that approximately $1-15 \%$ of textile dyes used are lost during the dyeing process and are released in effluents $[4,5]$.
The release of effluents into aquatic ecosystems may decrease the water transparency and solar radiation penetration, thus decreasing photosynthetic activity and gases solubility, causing irreversible damage to the flora and fauna [6].

The different pollutants produced by the textile industry can be treated by physical-chemical and/or biological processes, which, like other technological processes for wastewater treatment, have advantages and disadvantages. Biological processes are widely used for the treatment of textile wastewaters, usually in combination with a physicalchemical posttreatment. However, these processes usually demand high hydraulic retention times (HRT) and transfer part of the dyes to a different phase, leading to other environmental consequences (sludge) $[7,8]$. Moreover, trace amounts of dioxins and furans can be formed as byproducts of incomplete oxidation [9]. Because of these limitations as well as the low efficiencies that can be found with many dye 


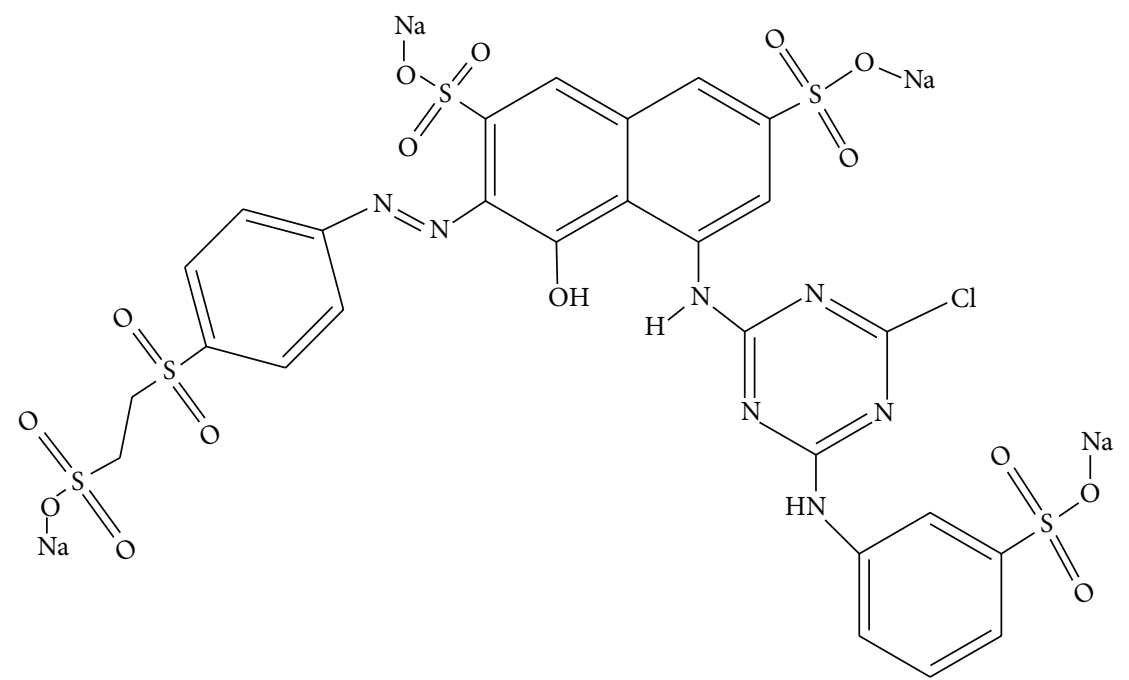

FIGURE 1: Chemical structure of the sulfonated azo dye Reactive Red 198 (RR).

classes, new technologies for the treatment of effluents from textile industry have been developed.

Advanced oxidation processes (AOPs) are highly effective at destroying organic compounds that are difficult to degrade. They function by generating hydroxyl radicals that act as a very reactive oxidizing agent and can quickly and nonselectively cleave chemical bonds, leading to partial or complete mineralization of the contaminant. Examples of AOPs include $\mathrm{Fe} / \mathrm{H}_{2} \mathrm{O}_{2}, \mathrm{UV} / \mathrm{O}_{3}, \mathrm{O}_{3} / \mathrm{H}_{2} \mathrm{O}_{2}, \mathrm{O}_{3} / \mathrm{UV} / \mathrm{H}_{2} \mathrm{O}_{2}$, $\mathrm{UV} / \mathrm{TiO}_{2}$, and $\mathrm{UV} / \mathrm{H}_{2} \mathrm{O}_{2}$, and the use of this technology on textile wastewater is well documented [10-14].

A combined process using UV and $\mathrm{H}_{2} \mathrm{O}_{2}$ is one of the AOPs that have been successfully applied to the treatment of various aqueous pollutants [15]. Oxidation processes are associated with very reactive species, such as hydroxyl radicals, which are generated by the direct photolysis of $\mathrm{H}_{2} \mathrm{O}_{2}$ under UV irradiation [16]:

$$
\mathrm{H}_{2} \mathrm{O}_{2}+h v \longrightarrow 2 \mathrm{HO}^{\bullet} \quad \Phi^{\mathrm{pri}} I_{a, \mathrm{H}_{2} \mathrm{O}_{2}}
$$

This study investigated the use of $\mathrm{UV} / \mathrm{H}_{2} \mathrm{O}_{2}$ system on degradation of the sulfonated azo dye Reactive Red 198 (RR), Figure 1. The kinetics of dye decolorization were determined as well as the effects of hydrogen peroxide concentration, temperature, $\mathrm{pH}$, and the in-line addition of hydrogen peroxide on dye removal.

\section{Materials and Methods}

2.1. Reagents. Reactive Red 198 (RR) (CAS 145017-98-7) was supplied by $D y S t a r$ and was used to test the dye degradation capacities: hydrogen peroxide $(30 \% \mathrm{w} / \mathrm{w})$ (SYNTH), sodium hydroxide $(\mathrm{NaOH})$ (VETEC), and sulfuric acid $\left(\mathrm{H}_{2} \mathrm{SO}_{4}\right)$ (SYNTH). All solutions were prepared with deionized water (Milli-Q Academic-Millipore).

The molecular weight of Reactive Red is approximately $968.2 \mathrm{~g} / \mathrm{mol}$. The chemical oxygen demand (COD) of a solution containing $1 \mathrm{~g} / \mathrm{L}$ of this dye is $2381.30 \mathrm{mg} \mathrm{O}_{2} / \mathrm{L}$. The UVVIS absorption spectrum at a concentration of $1 \mathrm{~g} / \mathrm{L}$ (purity

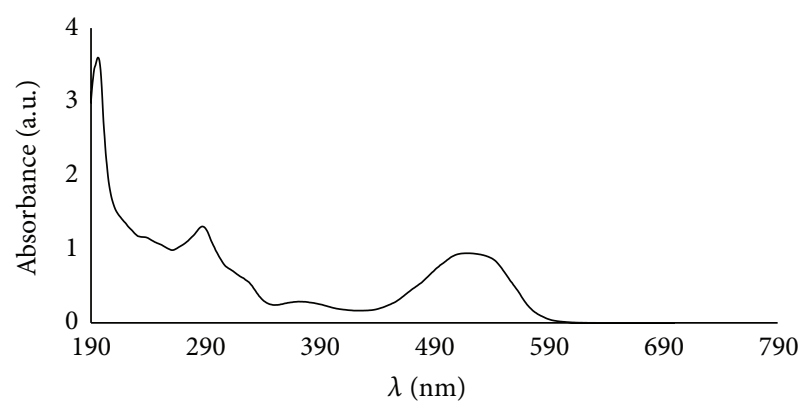

FIGURE 2: Spectrum of UV-VIS absorption of the sulfonated azo dye Reactive Red 198 (RR).

disregarded) showed a strong absorption peak at $520 \mathrm{~nm}$ (black line), characterized by the presence of azo group $(-\mathrm{N}=\mathrm{N}-)$ bound to aromatic rings, as shown in Figure 2.

2.2. $\mathrm{UV} / \mathrm{H}_{2} \mathrm{O}_{2}$ AOP Reactor. The dye degradation study was performed in an irradiation chamber $(95 \mathrm{~cm}$ long, $2.8 \mathrm{~cm}$ internal diameter, and useful volume $710 \mathrm{~mL}$ ) composed of a quartz tube and an ultraviolet (UV) source, a $30 \mathrm{~W}$ UV-C PHILIPS TUV-T5 low-pressure mercury vapor lamp with an intensity of $100 \mu \mathrm{W} / \mathrm{cm}^{2}$ (Figure 3).

The UV source was positioned inside the quartz tube; the dye solution was on the outside of the tube; hence, there was no direct contact between the UV source and the dye to be irradiated. A stainless steel reflective dome was placed over the experimental set-up to shield the rest of the laboratory from the UV radiation. The experiments were conducted in a glass jar covered with aluminum foil on a hot plate with magnetic stirring. Recirculation of the dye solution to be treated was performed using a peristaltic pump (GILSON, model Miniplus 3).

Three degradation systems were used: $\mathrm{UV}, \mathrm{H}_{2} \mathrm{O}_{2}$, and $\mathrm{UV} / \mathrm{H}_{2} \mathrm{O}_{2}$. All experiments were performed with a total volume of $2 \mathrm{~L}$ of the dye solution. The dye was dissolved in 


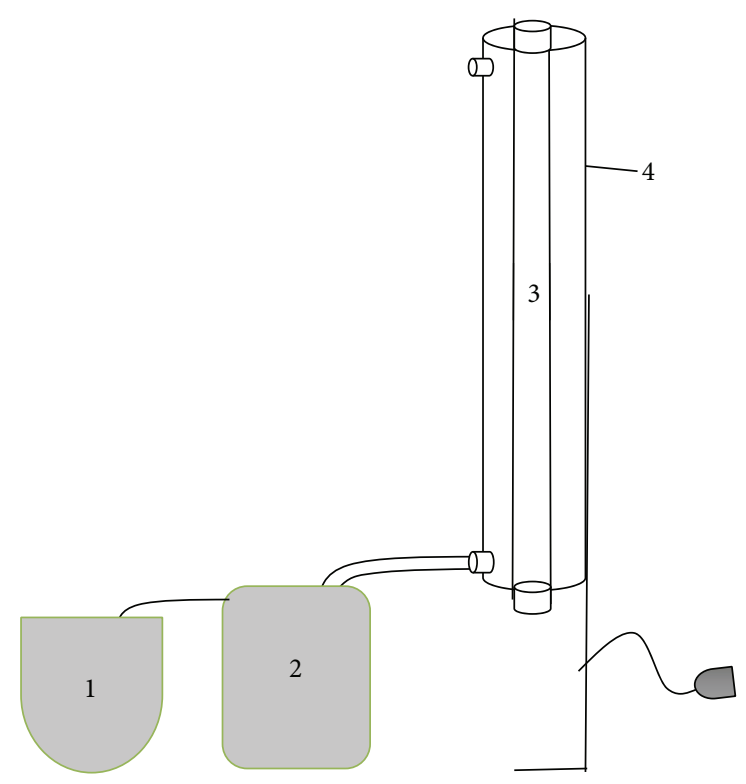

FIgURE 3: General schematic of the $\mathrm{UV} / \mathrm{H}_{2} \mathrm{O}_{2}$ AOP photochemical reactor (1: reservoir, 2: peristaltic pump, 3: UV lamp, and 4: photoreactor).

water and heated to a predetermined temperature, and then known amounts of hydrogen peroxide and $\mathrm{NaOH}$ or $\mathrm{H}_{2} \mathrm{SO}_{4}$ (to adjust the $\mathrm{pH}$ ) were added to the solution. All experiments were performed at a flow rate of $25 \mathrm{~mL} / \mathrm{min}$ and a hydraulic retention time (HRT) of 28.4 minutes. The decolorization rate and the effects of temperature, $\mathrm{pH}$, amount of hydrogen peroxide, and in-line addition of hydrogen peroxide were studied. All experiments were performed in duplicate.

\subsubsection{Effect of the Hydrogen Peroxide Concentration. The} effect of the hydrogen peroxide concentration on dye removal was evaluated using five different concentrations: $0.3,0.5,0.7$, 1 , and $2 \%(\mathrm{w} / \mathrm{v})$. The dye concentration used was $1.03 \mathrm{mM}$. In this part of the study, the experiments were performed using three degradation systems: $\mathrm{UV}, \mathrm{H}_{2} \mathrm{O}_{2}$, and $\mathrm{UV} / \mathrm{H}_{2} \mathrm{O}_{2}$. The total irradiation time was 240 minutes and the initial $\mathrm{pH}$ was 10. Determinations of residual $\mathrm{H}_{2} \mathrm{O}_{2}, \mathrm{pH}$, conductivity, color, and $\mathrm{COD}$ were performed every 60 minutes.

2.2.2. Effect of the Initial $p H$. After the investigation of the effect of the hydrogen peroxide concentration, experiments were performed with initial $\mathrm{pH}$ values of $3,6,8$, and 10 . This study was run using the $\mathrm{UV} / \mathrm{H}_{2} \mathrm{O}_{2}$ system, hydrogen peroxide concentration of $1 \%(\mathrm{w} / \mathrm{v})$, dye concentration of $1.03 \mathrm{mM}$, and temperature of $25^{\circ} \mathrm{C}$.

2.2.3. Effect of Temperature. After the evaluation of hydrogen peroxide concentration and initial $\mathrm{pH}$ influence on color and COD removals, experiments were performed to elucidate the influence of temperature. For this test, four temperatures were evaluated: $25,45,60$, and $80^{\circ} \mathrm{C}$. This study was performed using the $\mathrm{UV} / \mathrm{H}_{2} \mathrm{O}_{2}$ system, hydrogen peroxide concentration of $1 \%(\mathrm{w} / \mathrm{v})$, and dye concentration of $1.03 \mathrm{mM}$.
2.2.4. Effect of the In-Line Addition of Hydrogen Peroxide. The last part of the experiment consisted of an evaluation of inline hydrogen peroxide addition in the AOP reactor. Therefore, small amounts of $\mathrm{H}_{2} \mathrm{O}_{2}$ were added to the UV/ $\mathrm{H}_{2} \mathrm{O}_{2}$ system by using a peristaltic pump (GILSON, model Miniplus 3 ), in which the initial $\mathrm{pH}$ was 10 , hydrogen peroxide concentration of $1 \%(\mathrm{w} / \mathrm{v})$, dye concentration $1.03 \mathrm{mM}$, and temperature of $60^{\circ} \mathrm{C}$. It is worth mentioning that we added in-line the same volume of hydrogen peroxide used for the experiments 2.2.4, in which this compound was kept in a container with the dye and other chemicals.

2.3. Physical and Chemical Analyses. Dye characterization was performed by analyzing color, amount of residual peroxide, $\mathrm{pH}$, conductivity, and COD. The $\mathrm{pH}$ was measured with a digital $\mathrm{pH}$ meter (TECNAL microprocessor; model TEC5). Hydrogen peroxide concentration was determined using a volumetric titration method. Conductivity was measured with a SCIENTIFIC THERMO (Orion 5 Star) conductivity meter.

The color was determined using a spectrophotometer (Thermo-Nicolet Evolution 100) and scans were performed every 60 minutes. The samples were diluted $(1: 5)$ in ultrapure water and then centrifuged at $13000 \mathrm{rpm}$ for 2 minutes (Eppendorf, MiniSpin). Dye removal efficiency was estimated from the absorbance measurements according to

$$
\operatorname{Efficiency}(\%)=\left(1-\frac{[\mathrm{RR}]}{[\mathrm{RR}]_{0}}\right) \times 100,
$$

where $[R R]$ and $[R R]_{0}$ are final and initial concentration of Reactive Red 198, respectively. COD was determined photometrically (Thermo-Evolution Nicolet 100) according to standard methods (APHA, 2005). The residual concentration of hydrogen peroxide $\left(\mathrm{H}_{2} \mathrm{O}_{2}\right)$ is important because it affects the COD by consuming $\mathrm{K}_{2} \mathrm{Cr}_{2} \mathrm{O}_{7}$ [17]:

$$
\mathrm{Cr}_{2} \mathrm{O}_{7}{ }^{2-}+3 \mathrm{H}_{2} \mathrm{O}_{2}+8 \mathrm{H}^{+} \longrightarrow 2 \mathrm{Cr}^{3+}+3 \mathrm{O}_{2}+7 \mathrm{H}_{2} \mathrm{O}
$$

This interference can be corrected taking into account the COD of a hydrogen peroxide solution. After determining the residual hydrogen peroxide concentrations, corrections were made according to Lin and Lo [18] who reported that $1 \mathrm{~g} / \mathrm{L}$ of hydrogen peroxide corresponds to COD of $270 \mathrm{mg} / \mathrm{L}$.

\section{Results and Discussion}

3.1. Effect of the Hydrogen Peroxide Concentration. The effect of the oxidant concentration $\left(\mathrm{H}_{2} \mathrm{O}_{2}\right)$ was assessed in the $\mathrm{H}_{2} \mathrm{O}_{2}$, UV/ $\mathrm{H}_{2} \mathrm{O}_{2}$, and UV degradation systems. During $\mathrm{UV} / \mathrm{H}_{2} \mathrm{O}_{2}$ treatment, it was observed that increasing the concentration of hydrogen peroxide from 0.3 to $1 \%$ an increase in color removal was observed (Figure 4). However, a negative effect was found when the hydrogen peroxide concentration was $2 \%$. A negative effect of hydrogen peroxide on the decolorization rates was also verified on Chang et al. [19]. The color removal in the presence of only hydrogen peroxide (1\%) or UV was negligible. Elmorsi et al. [20] also observed this effect in their study, demonstrating that the combination of $\mathrm{UV}$ and $\mathrm{H}_{2} \mathrm{O}_{2}$ is necessary. 
TABLE 1: Effect of the irradiation time and hydrogen peroxide concentration in some physical-chemical parameters. Experimental conditions: $25^{\circ} \mathrm{C}$ and initial $\mathrm{pH}$ of 10 .

\begin{tabular}{|c|c|c|c|c|}
\hline Treatment & Time $(\min )$ & $\mathrm{pH}$ & Conductivity $(\mu \mathrm{S} / \mathrm{cm})$ & $\mathrm{H}_{2} \mathrm{O}_{2}$ residual (\%) \\
\hline \multirow{5}{*}{$\mathrm{UV} / 0.3 \% \mathrm{H}_{2} \mathrm{O}_{2}$} & 0 & $10.00 \pm 0.02$ & $811.00 \pm 2.81$ & $0.30 \pm 0.01$ \\
\hline & 60 & $8.24 \pm 0.12$ & $947.00 \pm 12.73$ & $0.28 \pm 0.04$ \\
\hline & 120 & $3.93 \pm 0.09$ & $982.50 \pm 12.02$ & $0.26 \pm 0.03$ \\
\hline & 180 & $3.30 \pm 0.08$ & $1097.50 \pm 8.25$ & $0.23 \pm 0.02$ \\
\hline & 240 & $3.95 \pm 0.11$ & $1345.00 \pm 6.33$ & $0.20 \pm 0.03$ \\
\hline \multirow{5}{*}{$\mathrm{UV} / 0.5 \% \mathrm{H}_{2} \mathrm{O}_{2}$} & 0 & $10.00 \pm 0.03$ & $811.00 \pm 2.82$ & $0.50 \pm 0.02$ \\
\hline & 60 & $8.89 \pm 0.08$ & $1068.00 \pm 7.31$ & $0.47 \pm 0.03$ \\
\hline & 120 & $5.13 \pm 0.13$ & $1137.00 \pm 10.15$ & $0.44 \pm 0.05$ \\
\hline & 180 & $4.00 \pm 0.09$ & $1241.00 \pm 12.48$ & $0.39 \pm 0.03$ \\
\hline & 240 & $3.46 \pm 0.12$ & $1385.50 \pm 8.42$ & $0.30 \pm 0.02$ \\
\hline \multirow{5}{*}{$\mathrm{UV} / 0.7 \% \mathrm{H}_{2} \mathrm{O}_{2}$} & 0 & $10.00 \pm 0.03$ & $811.00 \pm 2.80$ & $0.70 \pm 0.01$ \\
\hline & 60 & $9.68 \pm 0.13$ & $1246.00 \pm 5.81$ & $0.67 \pm 0.03$ \\
\hline & 120 & $6.75 \pm 0.12$ & $1293.00 \pm 12.30$ & $0.64 \pm 0.02$ \\
\hline & 180 & $5.84 \pm 0.10$ & $1330.00 \pm 7.05$ & $0.58 \pm 0.04$ \\
\hline & 240 & $5.55 \pm 0.12$ & $1445.00 \pm 9.02$ & $0.41 \pm 0.02$ \\
\hline \multirow{5}{*}{$\mathrm{UV} / 1 \% \mathrm{H}_{2} \mathrm{O}_{2}$} & 0 & $10.00 \pm 0.02$ & $811.00 \pm 2.81$ & $1.00 \pm 0.02$ \\
\hline & 60 & $9.96 \pm 0.14$ & $1591.00 \pm 13.21$ & $0.93 \pm 0.05$ \\
\hline & 120 & $7.99 \pm 0.10$ & $1630.00 \pm 8.36$ & $0.88 \pm 0.03$ \\
\hline & 180 & $6.66 \pm 0.15$ & $1563.50 \pm 7.05$ & $0.77 \pm 0.03$ \\
\hline & 240 & $6.59 \pm 0.09$ & $1620.50 \pm 6.87$ & $0.31 \pm 0.04$ \\
\hline \multirow{5}{*}{$\mathrm{UV} / 2 \% \mathrm{H}_{2} \mathrm{O}_{2}$} & 0 & $10.00 \pm 0.03$ & $811.00 \pm 2.80$ & $2.00 \pm 0.02$ \\
\hline & 60 & $9.77 \pm 0.06$ & $1890.00 \pm 12.45$ & $1.86 \pm 0.04$ \\
\hline & 120 & $9.35 \pm 0.14$ & $1942.00 \pm 6.39$ & $1.63 \pm 0.03$ \\
\hline & 180 & $8.40 \pm 0.13$ & $1957.50 \pm 10.40$ & $1.36 \pm 0.03$ \\
\hline & 240 & $7.82 \pm 0.10$ & $2011.00 \pm 8.27$ & $1.04 \pm 0.02$ \\
\hline \multirow{5}{*}{$1 \% \mathrm{H}_{2} \mathrm{O}_{2}$} & 0 & $10.00 \pm 0.02$ & $811.00 \pm 2.79$ & $1.00 \pm 0.01$ \\
\hline & 60 & $9.81 \pm 0.10$ & $1488.00 \pm 6.30$ & $0.94 \pm 0.02$ \\
\hline & 120 & $9.74 \pm 0.09$ & $1506.00 \pm 5.49$ & $0.90 \pm 0.01$ \\
\hline & 180 & $9.69 \pm 0.12$ & $1510.00 \pm 10.26$ & $0.87 \pm 0.02$ \\
\hline & 240 & $9.62 \pm 0.08$ & $1518.50 \pm 11.10$ & $0.86 \pm 0.02$ \\
\hline \multirow{5}{*}{ UV } & 0 & $10.00 \pm 0.2$ & $811.00 \pm 2.80$ & - \\
\hline & 60 & $8.47 \pm 0.11$ & $832.00 \pm 8.02$ & - \\
\hline & 120 & $7.86 \pm 0.9$ & $845.00 \pm 12.91$ & - \\
\hline & 180 & $7.73 \pm 0.8$ & $859.00 \pm 10.35$ & - \\
\hline & 240 & $7.55 \pm 0.10$ & $861.00 \pm 7.48$ & - \\
\hline
\end{tabular}

Table 1 presents the changes in the physical-chemical properties for each condition studied. The conductivity results generally show increases for all treatments (Table 1) which are most likely either due to the addition of hydrogen peroxide at the beginning of the experiment or due to the formation of ions in the solution after dye bond cleavage. For instance, some authors have observed the formation of $\mathrm{NO}_{3}{ }^{-}$, $\mathrm{SO}_{4}{ }^{2-}$, and $\mathrm{Cl}^{-}$during the mineralization of Reactive Red 198 [21].

The analyses confirmed a $\mathrm{pH}$ decrease for all treatments (Table 1), most likely due to the formation of acidic substances by hydroxyl radicals during dye removal. Similar results were found by Kowalska et al. [22]. For instance, Mahmoodi et al. [21] reported the formation of organic carboxylic acids during the photocatalytic degradation of triazinic ring-containing azo dye (Reactive Red 198) by using immobilized $\mathrm{TiO}_{2}$ photoreactor. The results for the residual peroxide concentration (Table 1) showed a gradual decrease in this concentration for all treatments, most likely due to the formation of hydroxyl radicals from hydrogen peroxide cleavage.

COD removal varied from $14.83 \%$ to $78.41 \%$ and the $\mathrm{UV} / 1 \% \mathrm{H}_{2} \mathrm{O}_{2}$ treatment was the most efficient (Figure 5). The good performance was linked to higher amount of hydroxyl radicals formed. However, no improvement in either color or COD removals was found when the $\mathrm{H}_{2} \mathrm{O}_{2}$ concentration increased from 1 to $2 \%$ (Figure 5). Therefore, $\mathrm{UV} / 1 \% \mathrm{H}_{2} \mathrm{O}_{2}$ was selected for the subsequent studies. 


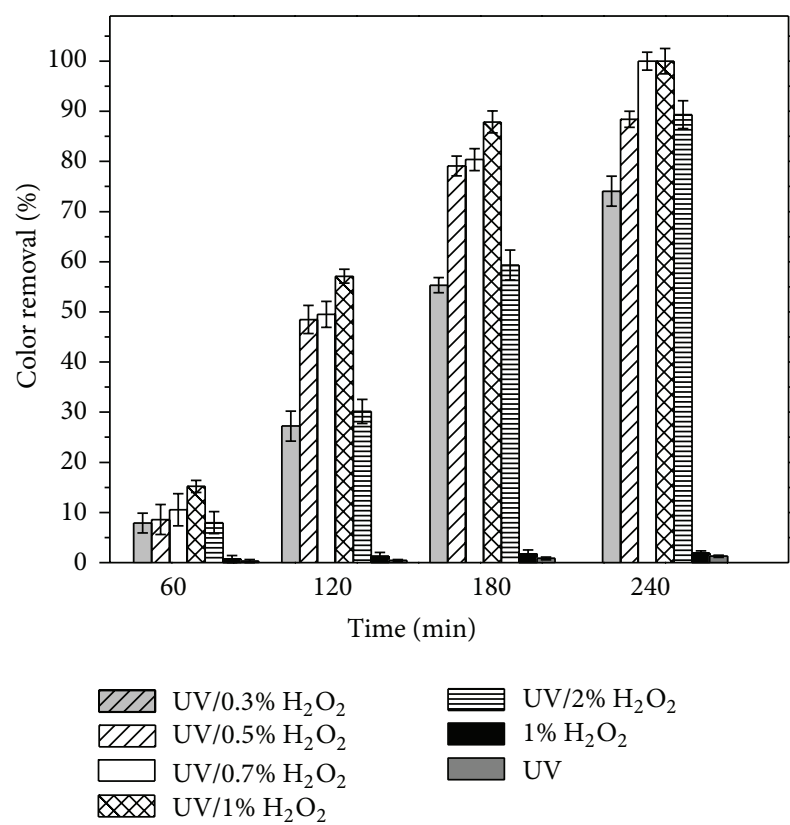

Figure 4: Effect of hydrogen peroxide dosage on color removal. Experimental conditions: $25^{\circ} \mathrm{C}$ and initial $\mathrm{pH}$ of 10 .
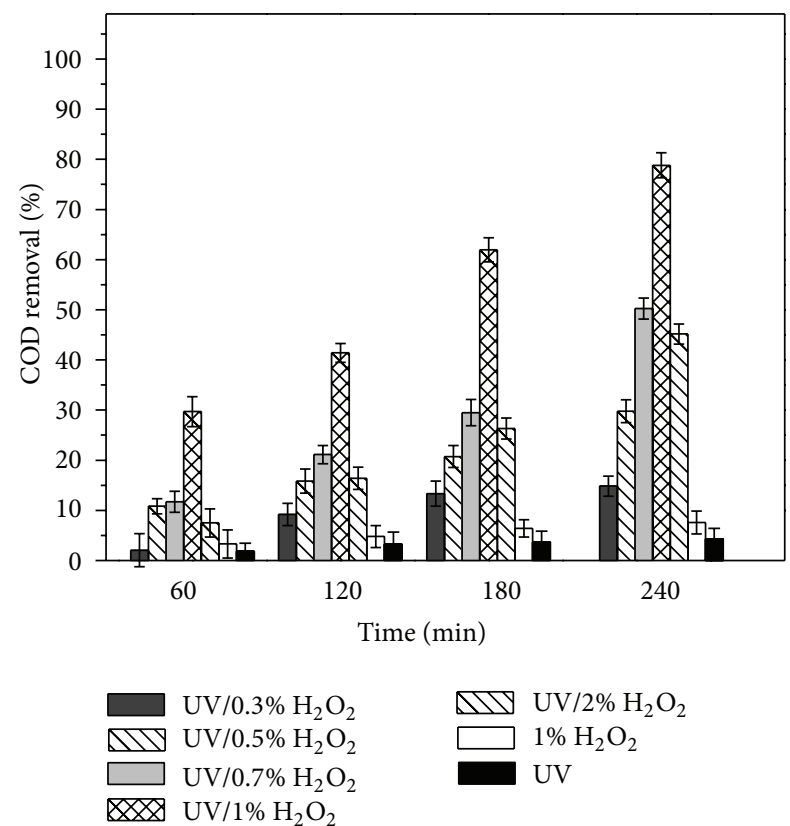

Figure 5: Effect of hydrogen peroxide dosage on COD removal. Experimental conditions: $25^{\circ} \mathrm{C}$ and initial $\mathrm{pH}$ of 10 .

According to Kalsoom et al. when low-pressure mercury vapor lamps and low concentrations of peroxide are used in AOP system, the amount of UV absorption during the generation of hydroxyl radicals is insignificant [23]. Published studies showed that increasing the concentration of hydrogen peroxide leads to a subsequent increase in the hydroxyl radical production. Excess hydrogen peroxide in the reaction may decrease the process efficiency since this

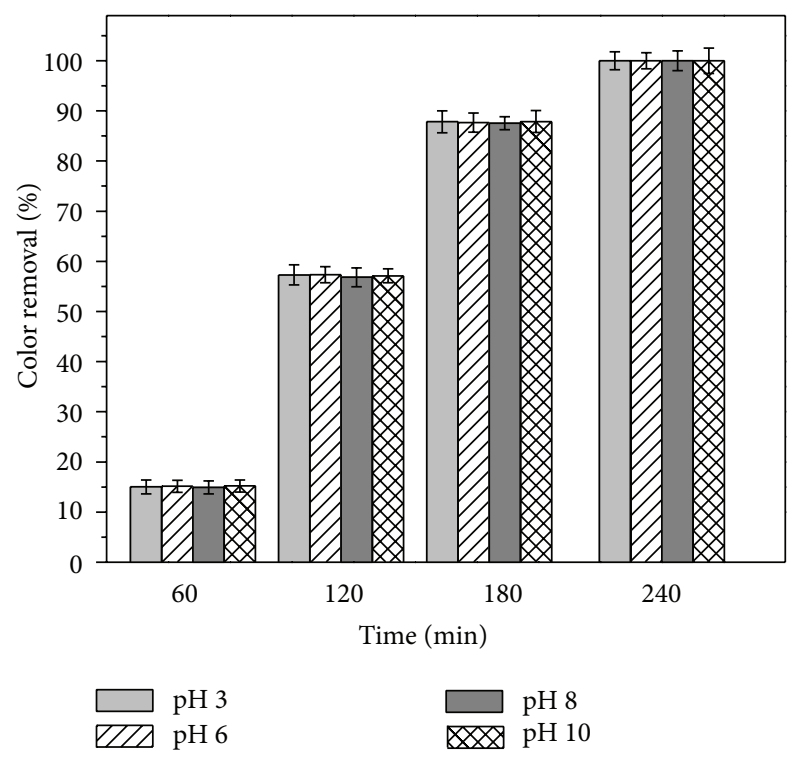

FIGURE 6: Effect of the initial $\mathrm{pH}$ on color removal. Experimental conditions: $\mathrm{UV} / 1 \% \mathrm{H}_{2} \mathrm{O}_{2}$ and $25^{\circ} \mathrm{C}$.

compound is able to scavenge hydroxyl radicals to form water and hydroperoxyl radicals $\left(\mathrm{HO}_{2}{ }^{\circ}\right)$, thus initiating other reactions that affect the oxidation process [19]:

$$
\begin{gathered}
\mathrm{H}_{2} \mathrm{O}_{2}+\mathrm{HO}^{\bullet} \longrightarrow \mathrm{HO}_{2}^{\cdot}+\mathrm{H}_{2} \mathrm{O} \quad k_{1}=2,7 \times 10^{7} \mathrm{M}^{-1} \mathrm{~S}^{-1} \\
\mathrm{H}_{2} \mathrm{O}_{2}+\mathrm{HO}_{2}{ }^{-} \longrightarrow \mathrm{HO}^{\bullet}+\mathrm{O}_{2}+\mathrm{H}_{2} \mathrm{O} \quad k_{2}=3,0 \mathrm{M}^{-1} \mathrm{~S}^{-1} \\
\mathrm{H}_{2} \mathrm{O}_{2}+\mathrm{HO}^{\bullet} \longrightarrow \mathrm{O}_{2}^{\cdot-}+\mathrm{H}^{+}+\mathrm{H}_{2} \mathrm{O} \\
k_{3}=2,7 \times 10^{7} \mathrm{M}^{-1} \mathrm{~S}^{-1} \\
\mathrm{H}_{2} \mathrm{O}_{2}+\mathrm{O}_{2}^{\cdot-} \longrightarrow \mathrm{HO}^{\bullet}+\mathrm{OH}^{-}+\mathrm{O}_{2} \quad k_{4}=0,13 \mathrm{M}^{-1} \mathrm{~S}^{-1} .
\end{gathered}
$$

3.2. Effect of the Initial $p H$. According to the results shown in Figure 6, pH had no influence on the color removal capacity. Elmorsi et al. [20] also found no differences in color removal varying the $\mathrm{pH}$ from 2 to 9 , which is in agreement with our observations. Under a technological perspective this is an important characteristic and an advantage of the $\mathrm{UV} / \mathrm{H}_{2} \mathrm{O}_{2}$ AOP system because there is no need of $\mathrm{pH}$ corrections in the treatment plant and usually the $\mathrm{pH}$ of textile wastewaters is alkaline.

Table 2 displays the results of the physical-chemical analyses highlighting an increase in the conductivity after treatment. However, it was observed that at higher $\mathrm{pH}$ values, there was a greater variation between initial and final conductivities. This was likely due to further molecular fragmentations leading to ionized reaction products.

The residual peroxide concentrations decreased for all treatments, but it is worth noting that, at basic $\mathrm{pH}$ values, there is a higher rate of peroxide decomposition (Table 2), 
TABLE 2: Effect of the irradiation time and $\mathrm{pH}$ in some physical-chemical parameters. Experimental conditions: $\mathrm{UV} / 1 \% \mathrm{H}_{2} \mathrm{O}_{2}$ and $25^{\circ} \mathrm{C}$.

\begin{tabular}{|c|c|c|c|c|}
\hline Initial pH & Time (min) & $\mathrm{pH}$ & Conductivity $(\mu \mathrm{S} / \mathrm{cm})$ & $\mathrm{H}_{2} \mathrm{O}_{2}$ residual (\%) \\
\hline \multirow{5}{*}{3.0} & 0 & $3.00 \pm 0.02$ & $1067.00 \pm 1.78$ & $1.00 \pm 0.01$ \\
\hline & 60 & $2.86 \pm 0.05$ & $1131.20 \pm 6.32$ & $0.95 \pm 0.03$ \\
\hline & 120 & $2.73 \pm 0.06$ & $1357.40 \pm 10.57$ & $0.91 \pm 0.02$ \\
\hline & 180 & $2.69 \pm 0.07$ & $1501.10 \pm 11.34$ & $0.87 \pm 0.02$ \\
\hline & 240 & $2.85 \pm 0.04$ & $1394.34 \pm 8.10$ & $0.45 \pm 0.01$ \\
\hline \multirow{5}{*}{6.0} & 0 & $6.00 \pm 0.03$ & $718.00 \pm 2.02$ & $1.00 \pm 0.02$ \\
\hline & 60 & $3.54 \pm 0.07$ & $826.40 \pm 9.12$ & $0.95 \pm 0.02$ \\
\hline & 120 & $2.90 \pm 0.09$ & $1119.80 \pm 6.44$ & $0.91 \pm 0.04$ \\
\hline & 180 & $2.95 \pm 0.10$ & $1279.30 \pm 10.71$ & $0.80 \pm 0.03$ \\
\hline & 240 & $3.14 \pm 0.06$ & $1195.60 \pm 12.17$ & $0.43 \pm 0.02$ \\
\hline \multirow{5}{*}{8.0} & 0 & $8.00 \pm 0.01$ & $761.00 \pm 2.31$ & $1.00 \pm 0.02$ \\
\hline & 60 & $3.64 \pm 0.08$ & $832.10 \pm 5.54$ & $0.94 \pm 0.03$ \\
\hline & 120 & $3.25 \pm 0.05$ & $1192.50 \pm 8.91$ & $0.90 \pm 0.02$ \\
\hline & 180 & $3.04 \pm 0.06$ & $1258.20 \pm 13.77$ & $0.80 \pm 0.05$ \\
\hline & 240 & $3.57 \pm 0.10$ & $1250.70 \pm 10.15$ & $0.32 \pm 0.03$ \\
\hline \multirow{5}{*}{10.0} & 0 & $10.00 \pm 0.02$ & $811.00 \pm 2.81$ & $1.00 \pm 0.02$ \\
\hline & 60 & $9.96 \pm 0.14$ & $1591.00 \pm 13.21$ & $0.93 \pm 0.05$ \\
\hline & 120 & $7.99 \pm 0.10$ & $1630.00 \pm 8.36$ & $0.88 \pm 0.03$ \\
\hline & 180 & $6.66 \pm 0.15$ & $1563.50 \pm 7.05$ & $0.77 \pm 0.03$ \\
\hline & 240 & $6.59 \pm 0.09$ & $1620.50 \pm 6.87$ & $0.31 \pm 0.04$ \\
\hline
\end{tabular}

as previously reported [24]. UV radiation, which promotes the formation of hydroxyl radicals, also favors the rate of peroxide decomposition. Legrini et al. [25] indicated that, at alkaline $\mathrm{pH}$, the rate of photolysis of $\mathrm{H}_{2} \mathrm{O}_{2}$ increases, likely due to $\mathrm{HO}_{2}{ }^{-}$anion formation, which has a higher molar absorption coefficient $\left(240 \mathrm{M}^{-1} \mathrm{~cm}^{-1}\right.$ at $\left.254 \mathrm{~nm}\right)$ than hydrogen peroxide $\left(18.6 \mathrm{M}^{-1} \mathrm{~cm}^{-1}\right.$ at the same wavelength). Some authors have reported that the rate of $\mathrm{H}_{2} \mathrm{O}_{2}$ decomposition (see (8)) increases as the $\mathrm{pH}$ value approaches to $\mathrm{pKa}$ value (11.7) [25]. The hydroxyl radical is deactivated approximately 100 times faster in the presence of the $\mathrm{HO}_{2}{ }^{-}$anion than in the presence of $\mathrm{H}_{2} \mathrm{O}_{2}$ (see (9) and (10)) [19]. Consider the following:

$$
\begin{gathered}
\mathrm{H}_{2} \mathrm{O}_{2}+\mathrm{HO}_{2}^{-} \longrightarrow \mathrm{H}_{2} \mathrm{O}+\mathrm{O}_{2}+\mathrm{OH}^{-} \\
\mathrm{HO}^{\bullet}+\mathrm{HO}_{2}^{-} \longrightarrow \mathrm{H}_{2} \mathrm{O}+{ }^{-} \mathrm{O}_{2} \\
\mathrm{HO}^{\bullet}+\mathrm{H}_{2} \mathrm{O}_{2} \longrightarrow \mathrm{H}_{2} \mathrm{O}+\mathrm{HO}_{2}{ }^{-}
\end{gathered}
$$

Contrary to the color removal, COD removal showed a $\mathrm{pH}$ dependence (initial values of $3,6,8$, and 10), which increases with the $\mathrm{pH}$ increase. The highest COD removal was found at an initial $\mathrm{pH}$ of 10 , which resulted in a reduction of $78.81 \%$ (Figure 7). This likely indicates that COD removal was not affected by the formation of the hydroperoxyl anion $\left(\mathrm{HO}_{2}{ }^{-}\right)$or maybe the dye oxidation by the hydroxyl radicals was not taking place initially in the chromophore, which is responsible for the observed color, but in the auxochromes. Therefore, further experiments to determine the oxidation pathways should be required.

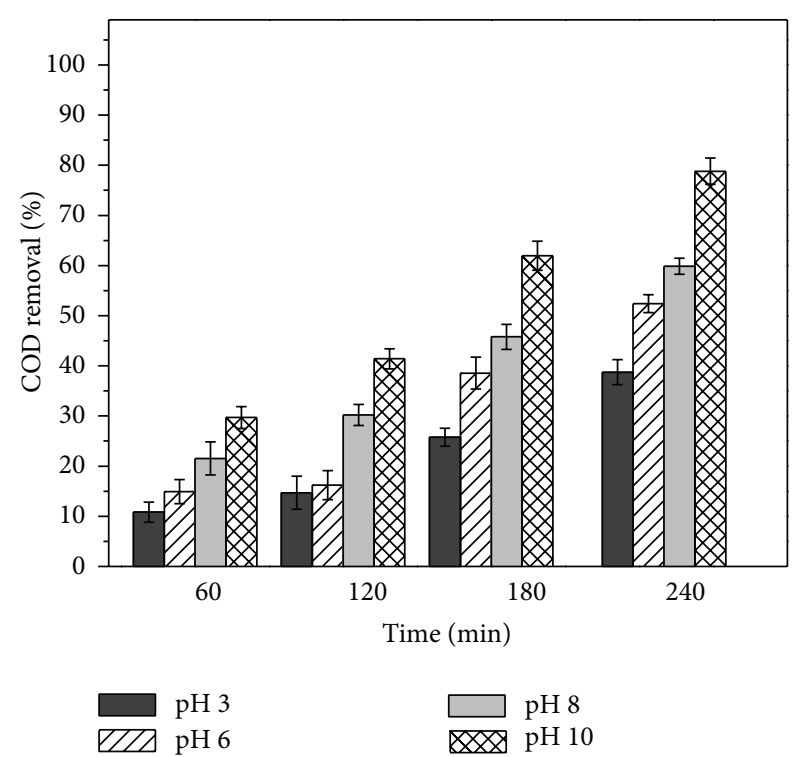

FIGURE 7: Effect of the initial $\mathrm{pH}$ on COD removal. Experimental conditions: $\mathrm{UV} / 1 \% \mathrm{H}_{2} \mathrm{O}_{2}$ and $25^{\circ} \mathrm{C}$.

3.3. Effect of Temperature. It is well known that usually textile wastewater is discharged at high temperatures. Hence, a study of the effect of temperature on dye removal was performed. The results presented in Figure 8 indicate that there was a small increase in the rate of decolorization by the temperature increase. However, the temperature of $80^{\circ} \mathrm{C}$ negatively impacted the process. 
TABLE 3: Effect of the irradiation time and temperature in some physical-chemical parameters. Experimental conditions: $\mathrm{UV} / 1 \% \mathrm{H}_{2} \mathrm{O}_{2}$ and initial $\mathrm{pH}$ of 10 .

\begin{tabular}{|c|c|c|c|c|}
\hline Temperature $\left({ }^{\circ} \mathrm{C}\right)$ & Time (min) & $\mathrm{pH}$ & Conductivity $(\mu \mathrm{S} / \mathrm{cm})$ & $\mathrm{H}_{2} \mathrm{O}_{2}$ residual (\%) \\
\hline \multirow{5}{*}{25} & 0 & $10.00 \pm 0.02$ & $811.00 \pm 2.81$ & $1.00 \pm 0.02$ \\
\hline & 60 & $9.96 \pm 0.14$ & $1591.00 \pm 13.21$ & $0.93 \pm 0.05$ \\
\hline & 120 & $7.99 \pm 0.10$ & $1630.00 \pm 8.36$ & $0.88 \pm 0.03$ \\
\hline & 180 & $6.66 \pm 0.15$ & $1563.50 \pm 7.05$ & $0.77 \pm 0.03$ \\
\hline & 240 & $6.59 \pm 0.09$ & $1620.50 \pm 6.87$ & $0.31 \pm 0.04$ \\
\hline \multirow{5}{*}{45} & 0 & $10.00 \pm 0.02$ & $811.00 \pm 2.80$ & $1.00 \pm 0.02$ \\
\hline & 60 & $9.74 \pm 0.09$ & $1682.50 \pm 15.28$ & $0.90 \pm 0.06$ \\
\hline & 120 & $8.24 \pm 0.15$ & $1693.80 \pm 16.42$ & $0.78 \pm 0.04$ \\
\hline & 180 & $7.05 \pm 0.17$ & $1727.30 \pm 12.23$ & $0.58 \pm 0.05$ \\
\hline & 240 & $6.70 \pm 0.16$ & $1790.70 \pm 10.11$ & $0.29 \pm 0.06$ \\
\hline \multirow{5}{*}{60} & 0 & $10.00 \pm 0.01$ & $811.00 \pm 2.79$ & $1.00 \pm 0.01$ \\
\hline & 60 & $9.94 \pm 0.11$ & $1695.40 \pm 14.35$ & $0.60 \pm 0.05$ \\
\hline & 120 & $8.17 \pm 0.13$ & $1712.20 \pm 12.40$ & $0.36 \pm 0.04$ \\
\hline & 180 & $7.13 \pm 0.12$ & $1766.30 \pm 17.53$ & $0.29 \pm 0.04$ \\
\hline & 240 & $6.72 \pm 0.15$ & $1802.10 \pm 15.41$ & $0.05 \pm 0.06$ \\
\hline \multirow{5}{*}{80} & 0 & $10.00 \pm 0.03$ & $811.00 \pm 2.82$ & $1.00 \pm 0.02$ \\
\hline & 60 & $9.84 \pm 0.08$ & $1783.20 \pm 15.26$ & $0.29 \pm 0.06$ \\
\hline & 120 & $9.72 \pm 0.13$ & $1799.70 \pm 13.44$ & $0.14 \pm 0.05$ \\
\hline & 180 & $8.61 \pm 0.17$ & $1831.50 \pm 11.55$ & $0.08 \pm 0.04$ \\
\hline & 240 & $6.88 \pm 0.15$ & $1884.20 \pm 14.40$ & $0.04 \pm 0.05$ \\
\hline
\end{tabular}

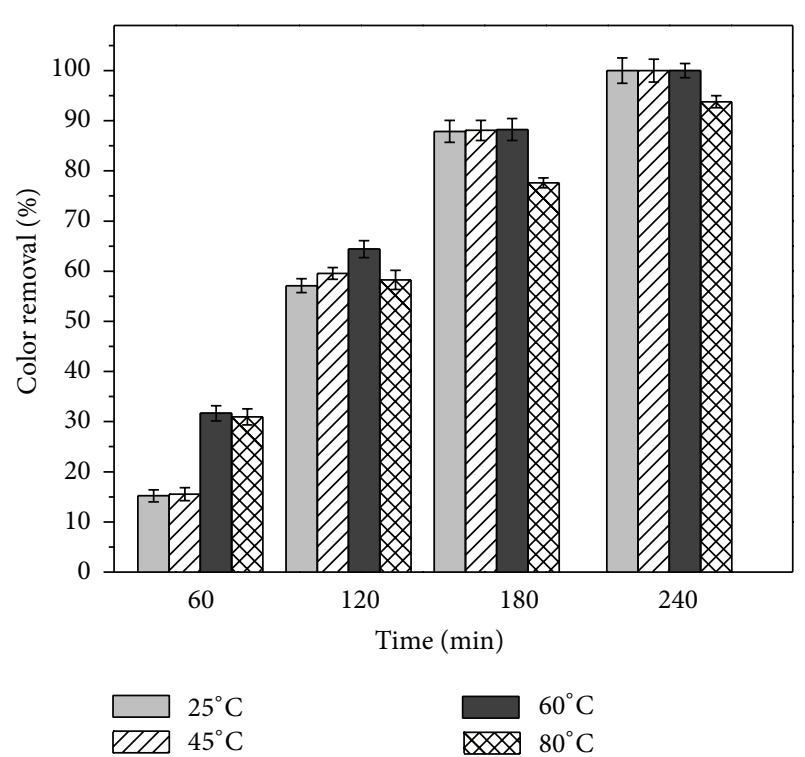

FIGURE 8: Effect of temperature on color removal. Experimental conditions: $\mathrm{UV} / 1 \% \mathrm{H}_{2} \mathrm{O}_{2}$ and initial $\mathrm{pH}$ of 10 .

The results for COD removal are shown in Figure 9 and a slight improvement was observed by the temperature increase. However, $80^{\circ} \mathrm{C}$ decreased $\mathrm{COD}$ removal, as negatively affecting color removal. The highest COD removal was found at $60^{\circ} \mathrm{C}$, which corresponded to $87.05 \%$.

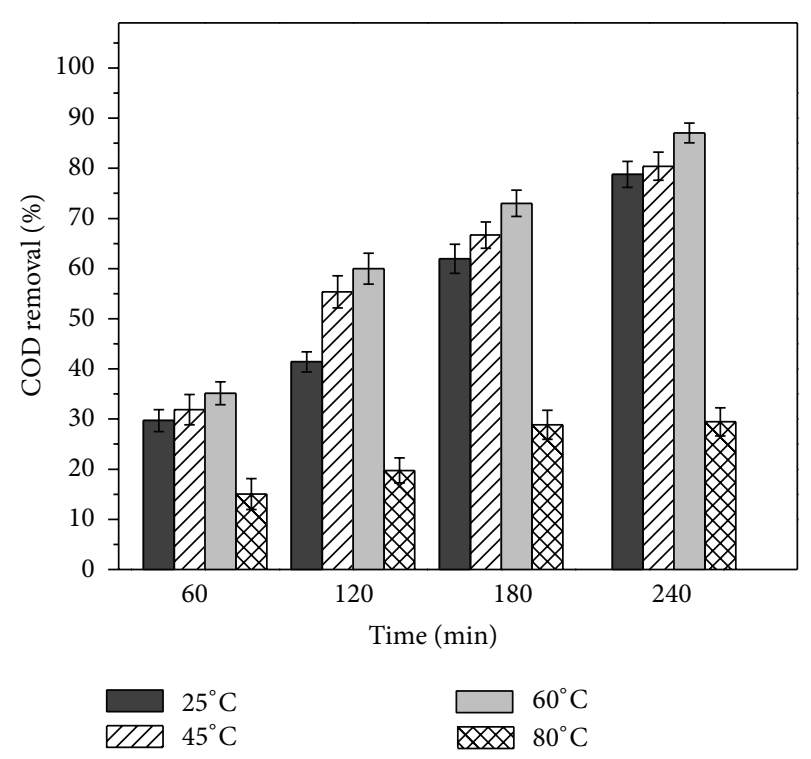

Figure 9: Effect of temperature on COD removal. Experimental conditions: $\mathrm{UV} / 1 \% \mathrm{H}_{2} \mathrm{O}_{2}$ and initial $\mathrm{pH}$ of 10 .

Another important point verified was the increase in the decomposition rate of hydrogen peroxide as the temperature increases (Table 3). For this parameter, $80^{\circ} \mathrm{C}$ was the best temperature. However, it seems that the species formed upon hydrogen peroxide oxidation were not involved either in 
color or in COD removals, as there was a decrease in the rates when the temperature changed from $60^{\circ} \mathrm{C}$ to $80^{\circ} \mathrm{C}$.

The $\mathrm{pH}$ did not vary significantly between the treatments but there was an increase in conductivity with the temperature increase (Table 3 ).

3.4. Kinetic Modeling. The $\mathrm{HO}^{\bullet}$ radicals in aqueous solution may be produced by UV irradiation and hydrogen peroxide (see (1)). To develop the kinetic model, we use (1) and (4)-(7) and compile the reaction steps:

$$
\begin{array}{cc}
\mathrm{RR}+\mathrm{HO}^{\bullet} \longrightarrow \mathrm{P} & k_{5} \\
\mathrm{~S}_{i}+\mathrm{HO}^{\bullet} \longrightarrow \mathrm{P}_{i} & k_{i}
\end{array}
$$

The reaction of hydroxyl radical with $\mathrm{S}_{i}$ corresponds to the reactions of the hydroxyl radical with other scavenger such as chloride, nitrate, sulfate, and carbonate. The corresponding kinetic equation of decolorization for $\mathrm{RR}$ is

$$
-\frac{d[\mathrm{RR}]}{d t}=k_{5}\left[\mathrm{HO}^{\bullet}\right][\mathrm{RR}]
$$

Considering the $\mathrm{HO}^{\circ}$ and $\mathrm{HO}_{2}{ }^{\bullet}$ radicals major species in decolorization,

$$
\begin{gathered}
\frac{d\left[\mathrm{HO}^{\bullet}\right]}{d t} \\
=2 \Phi^{\mathrm{pri}} I_{a, \mathrm{H}_{2} \mathrm{O}_{2}}-\left[\mathrm{H}_{2} \mathrm{O}_{2}\right]\left[\mathrm{HO}^{\bullet}\right] k_{1} \\
+\left[\mathrm{H}_{2} \mathrm{O}_{2}\right]\left[\mathrm{HO}_{2}^{\bullet}\right] k_{2}-\left[\mathrm{H}_{2} \mathrm{O}_{2}\right]\left[\mathrm{HO}^{\bullet}\right] k_{3} \\
+\left[\mathrm{H}_{2} \mathrm{O}_{2}\right]\left[\mathrm{O}_{2}^{\bullet-}\right] k_{4}-[\mathrm{RR}]\left[\mathrm{HO}^{\bullet}\right] k_{5} \\
\quad-\sum\left[\mathrm{S}_{i}\right]\left[\mathrm{HO}^{\bullet}\right] k_{i} \\
\frac{d\left[\mathrm{HO}_{2}^{\bullet}\right]}{d t}=\left[\mathrm{H}_{2} \mathrm{O}_{2}\right]\left[\mathrm{HO}^{\bullet}\right] k_{1}-\left[\mathrm{H}_{2} \mathrm{O}_{2}\right]\left[\mathrm{HO}_{2}{ }^{\bullet}\right] k_{2} .
\end{gathered}
$$

For state-steady approximation, it follows that

$$
\begin{aligned}
& \frac{d\left[\mathrm{HO}^{\bullet}\right]}{d t}=0 \\
& \frac{d\left[\mathrm{HO}_{2}^{\bullet}\right]}{d t}=0 .
\end{aligned}
$$

As a consequence of state-steady concentration and from (14)-(17), the concentration of hydroxyl radical can be described by (21):

$$
\left[\mathrm{HO}^{\bullet}\right]=\frac{2 \Phi^{\mathrm{pri}} I_{a, \mathrm{H}_{2} \mathrm{O}_{2}}+\left[\mathrm{H}_{2} \mathrm{O}_{2}\right]\left[\mathrm{O}_{2}^{\cdot-}\right] k_{4}}{\left[\mathrm{H}_{2} \mathrm{O}_{2}\right] k_{3}+[\mathrm{RR}] k_{5}+\sum\left[\mathrm{S}_{i}\right] k_{i}}
$$

where $\phi^{\text {pri }}$ is the initial quantum yield of hydrogen peroxide disappearance, equal to 0.5 , and $I_{a, \mathrm{H}_{2} \mathrm{O}_{2}}$ is the radiation intensity absorbed by $\mathrm{H}_{2} \mathrm{O}_{2}$.

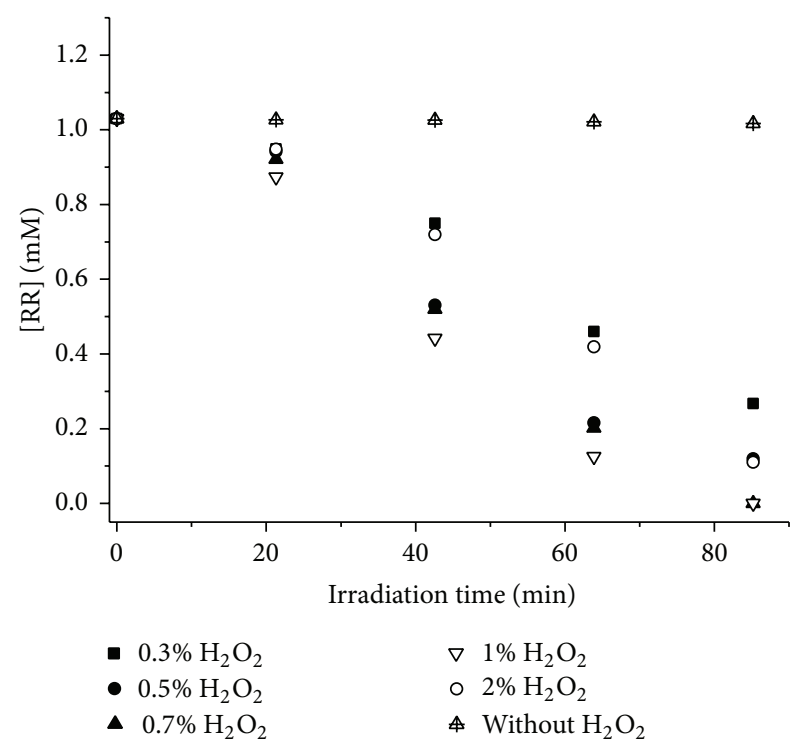

FIGURE 10: Zero order representation for RR decolorization versus time; $\mathrm{pH}=10 ; \mathrm{T}=25^{\circ} \mathrm{C}$; the irradiation time calculated from the hydraulic detention time (HDT).

$$
\begin{aligned}
& \text { Also, } \\
& I_{a, \mathrm{H}_{2} \mathrm{O}_{2}} \\
& =I_{0} f_{\mathrm{H}_{2} \mathrm{O}_{2}}\left\{1-\exp \left[-2.3 l\left(\varepsilon_{\mathrm{H}_{2} \mathrm{O}_{2}}\left[\mathrm{H}_{2} \mathrm{O}_{2}\right]+\varepsilon_{\mathrm{RR}}[\mathrm{RR}]\right)\right]\right\} \\
& \qquad f_{\mathrm{H}_{2} \mathrm{O}_{2}}=\frac{\varepsilon_{\mathrm{H}_{2} \mathrm{O}_{2}}\left[\mathrm{H}_{2} \mathrm{O}_{2}\right]}{\varepsilon_{\mathrm{H}_{2} \mathrm{O}_{2}}\left[\mathrm{H}_{2} \mathrm{O}_{2}\right]+\varepsilon_{\mathrm{RR}}[\mathrm{RR}]} .
\end{aligned}
$$

In (19), $I_{0}$ is the incident UV light intensity, $l$ is the optical path length of system, and $\varepsilon_{\mathrm{H}_{2} \mathrm{O}_{2}}$ and $\varepsilon_{\mathrm{RR}}$ are the molar extinction coefficient for $\mathrm{H}_{2} \mathrm{O}_{2}$ and $\mathrm{RR}$, respectively. Considering the RR and $\mathrm{H}_{2} \mathrm{O}_{2}$ having a high absorbance in the early stages of the process,

$$
1-\exp \left[-2.3 l\left(\varepsilon_{\mathrm{H}_{2} \mathrm{O}_{2}}\left[\mathrm{H}_{2} \mathrm{O}_{2}\right]+\varepsilon_{\mathrm{RR}}[\mathrm{RR}]\right)\right] \approx 1 .
$$

And $\left[\mathrm{O}_{2}{ }^{--}\right] k_{4} \ll 1$, it can be written as

$$
\left[\mathrm{HO}^{\bullet}\right]=\frac{2 \Phi^{\mathrm{pri}} I_{0} f_{\mathrm{H}_{2} \mathrm{O}_{2}}}{\left[\mathrm{H}_{2} \mathrm{O}_{2}\right] k_{3}+[\mathrm{RR}] k_{5}+\sum\left[\mathrm{S}_{i}\right] k_{i}} .
$$

And then (22) can be changed into (13):

$$
-\frac{d[\mathrm{RR}]}{d t}=k_{5} \frac{2 \Phi^{\mathrm{pri}} I_{0} f_{\mathrm{H}_{2} \mathrm{O}_{2}}}{\left[\mathrm{H}_{2} \mathrm{O}_{2}\right] k_{3}+[\mathrm{RR}] k_{5}+\sum\left[\mathrm{S}_{i}\right] k_{i}}[\mathrm{RR}] .
$$

In the present study, the results, Figure 10, show that the decolorization of dye RR corresponds to zero order kinetics; thus $[\mathrm{RR}] k_{5} \gg \sum\left[\mathrm{S}_{i}\right] k_{i}+\left[\mathrm{H}_{2} \mathrm{O}_{2}\right] k_{3}$, and the overall rate expression simplifies:

$$
-\frac{d[\mathrm{RR}]}{d t}=2 \Phi^{\mathrm{pri}} I_{0} f_{\mathrm{H}_{2} \mathrm{O}_{2}} .
$$

The results in Table 4 reveal that $k_{0}$ increases with increasing concentration of $\mathrm{H}_{2} \mathrm{O}_{2}$ and decreases above at $1 \%$. 
TABLE 4: Zero order rate constant for RR decolorization under different $\% \mathrm{H}_{2} \mathrm{O}_{2}$.

\begin{tabular}{|c|c|c|c|c|c|c|}
\hline & \multicolumn{6}{|c|}{$\mathrm{H}_{2} \mathrm{O}_{2}$} \\
\hline & $0.3 \%$ & $0.5 \%$ & $0.7 \%$ & $1 \%$ & $2 \%$ & Without \\
\hline$k_{0}$ & 0,0095 & 0,0120 & 0,0130 & 0,0132 & 0,0111 & 0,0001 \\
\hline$R$ & 0,985 & 0,976 & 0,987 & 0,984 & 0,981 & 0,977 \\
\hline
\end{tabular}

TABLE 5: Effect of the irradiation time and in-line addition in some physical-chemical parameters. Experimental conditions: initial pH of 10 and $60^{\circ} \mathrm{C}$.

\begin{tabular}{lcccc}
\hline Treatment & Time $(\mathrm{min})$ & $\mathrm{pH}$ & Conductivity $(\mu \mathrm{S} / \mathrm{cm})$ & $\mathrm{H}_{2} \mathrm{O}_{2}$ residual $(\%)$ \\
\hline & 0 & $10.00 \pm 0.01$ & $811.00 \pm 2.79$ & $1.00 \pm 0.01$ \\
$\mathrm{UV} / 1 \% \mathrm{H}_{2} \mathrm{O}_{2} / 60^{\circ} \mathrm{C}$ & 60 & $9.94 \pm 0.11$ & $1695.40 \pm 14.35$ & $0.60 \pm 0.05$ \\
(beginning of the & 120 & $8.17 \pm 0.13$ & $1712.20 \pm 12.40$ & $0.36 \pm 0.04$ \\
experiment) & 180 & $7.13 \pm 0.12$ & $1766.30 \pm 17.53$ & $0.29 \pm 0.04$ \\
& 240 & $6.72 \pm 0.15$ & $1802.10 \pm 15.41$ & $0.05 \pm 0.06$ \\
\hline & 0 & $10.00 \pm 0.02$ & $811.00 \pm 2.79$ & $0.00 \pm 0.00$ \\
$\mathrm{UV} / 1 \% \mathrm{H}_{2} \mathrm{O}_{2} / 60^{\circ} \mathrm{C}$ & 60 & $7.23 \pm 0.12$ & $1228.40 \pm 13.80$ & $0.74 \pm 0.06$ \\
(addition of $\mathrm{H}_{2} \mathrm{O}_{2}$ in-line) & 120 & $6.07 \pm 0.14$ & $1326.70 \pm 12.26$ & $0.69 \pm 0.04$ \\
& 180 & $5.23 \pm 0.13$ & $1347.20 \pm 16.93$ & $0.71 \pm 0.03$ \\
& 240 & $4.43 \pm 0.10$ & & $0.18 \pm 0.05$ \\
\hline
\end{tabular}

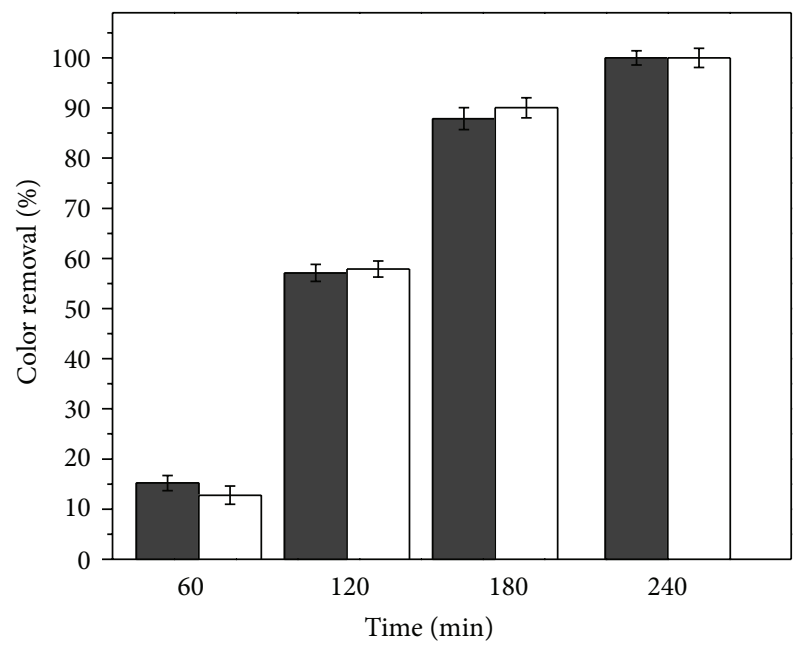

$\mathrm{UV} / 1 \% \mathrm{H}_{2} \mathrm{O}_{2}$ $\mathrm{UV} / 1 \% \mathrm{H}_{2} \mathrm{O}_{2}$ in-line

FIGURE 11: Effect of the in-line hydrogen peroxide addition on color removal. Experimental conditions: initial $\mathrm{pH} 10, \mathrm{UV} / 1 \% \mathrm{H}_{2} \mathrm{O}_{2}$, and $60^{\circ} \mathrm{C}$.

3.5. Effect of the In-Line Addition of Hydrogen Peroxide. The effect of the in-line peroxide addition was studied to determine if this operational strategy would benefit the process. The decolorization process was not significantly affected, although it should be noted that after 180 minutes of treatment, there was a slight improvement (Figure 11) compared to the conventional hydrogen peroxide feeding. A small but higher effect of hydrogen peroxide in-line addition was found for COD removal (Figure 12).

The results of the physical-chemical analyses are presented in Table 5. There was an increase in the conductivity

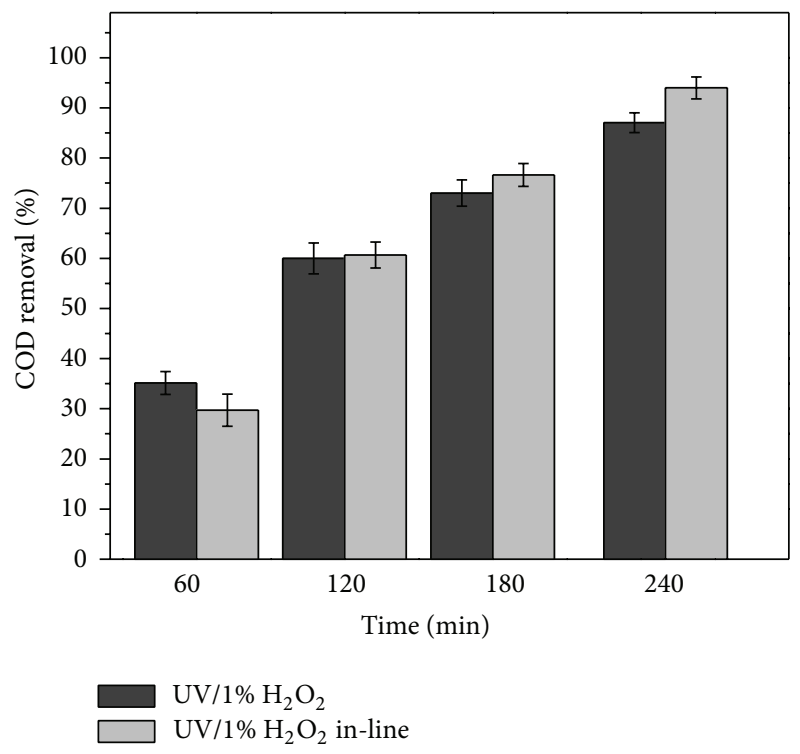

FIGURE 12: Effect of the in-line hydrogen peroxide addition on COD removal. Experimental conditions: initial $\mathrm{pH}$ of $10, \mathrm{UV} / 1 \% \mathrm{H}_{2} \mathrm{O}_{2}$, and $60^{\circ} \mathrm{C}$.

for the two operational strategies tested and a significant $\mathrm{pH}$ variation during in-line addition of $\mathrm{H}_{2} \mathrm{O}_{2}$.

The gradual addition of hydrogen peroxide may positively influence the mineralization process. This behavior can be explained by the fact that $\mathrm{H}_{2} \mathrm{O}_{2}$ in excess in solution, even under optimal operational conditions, is able to act as a hydroxyl radical $\left(\mathrm{HO}^{*}\right)$ scavenger. Additionally, intermediates can compete with the target molecules of the $\mathrm{HO}^{\circ}$ radicals. Nonetheless, an economic evaluation should be done to verify if a new line is composed of a different pump (including energy costs) as well as a separate container for 
stock solution, mixer, and so forth, would be compensated by the efficiency increase.

\section{Conclusions}

High color and COD removals were achieved by treating the sulfonated azo dye Reactive Red 198 by the $\mathrm{UV} / \mathrm{H}_{2} \mathrm{O}_{2}$ advanced oxidation process, even when low radiation times were used. $1 \% \mathrm{H}_{2} \mathrm{O}_{2}$ solution showed to be the best concentration, in which $2 \% \mathrm{H}_{2} \mathrm{O}_{2}$ decreased the process efficiency. The $\mathrm{pH}$ increase had a small effect on color removal but impacted positively COD removals. The same behavior was found for temperature increase, but changing from $60^{\circ} \mathrm{C}$ to $80^{\circ} \mathrm{C}$ resulted in a slight decrease for color removal and a sharp decrease for COD removal. In-line addition provided a small improvement in both color and COD removals. Therefore, the $\mathrm{UV} / \mathrm{H}_{2} \mathrm{O}_{2} \mathrm{AOP}$ system seems to be an interesting option for textile wastewaters and the most important parameters for color and COD removals are irradiation time and hydrogen peroxide concentration.

\section{Conflict of Interests}

The authors declare no conflict of interests in the research.

\section{Acknowledgments}

The authors would like to thank the Brazilian agencies CNPq, CAPES, and FUNCAP for the scholarship and financial support.

\section{References}

[1] F. Çiner and Ö. Gökkuş, "Treatability of dye solutions containing disperse dyes by fenton and fenton-solar light oxidation processes," Clean: Soil, Air, Water, vol. 41, no. 1, pp. 80-85, 2013.

[2] C. R. L. Souza and P. P. Zamora, "Degradação de corantes reativos pelo sistema ferro metálico/peróxido de hidrogênio," Química Nova, vol. 28, no. 2, pp. 226-228, 2005.

[3] H.-Y. Shu and W.-P. Hsieh, "Treatment of dye manufacturing plant effluent using an annular $\mathrm{UV} / \mathrm{H}_{2} \mathrm{O}_{2}$ reactor with multiUV lamps," Separation and Purification Technology, vol. 51, no. 3, pp. 379-386, 2006.

[4] C. Galindo, P. Jacques, and A. Kalt, "Photooxidation of the phenylazonaphthol $\mathrm{AO} 20$ on $\mathrm{TIO}_{2}$ : kinetic and mechanistic investigations," Chemosphere, vol. 45, no. 6-7, pp. 997-1005, 2001.

[5] N. Modirshahla and M. A. Behnajady, "Photooxidative degradation of Malachite Green (MG) by $\mathrm{UV} / \mathrm{H}_{2} \mathrm{O}_{2}$ : influence of operational parameters and kinetic modeling," Dyes and Pigments, vol. 70, no. 1, pp. 54-59, 2006.

[6] M. Vautier, C. Guillard, and J.-M. Herrmann, "Photocatalytic degradation of dyes in water: case study of indigo and of indigo carmine," Journal of Catalysis, vol. 201, no. 1, pp. 46-59, 2001.

[7] V. J. P. Vilar, L. X. Pinho, A. M. A. Pintor, and R. A. R. Boaventura, "Treatment of textile wastewaters by solar-driven advanced oxidation processes," Solar Energy, vol. 85, no. 9, pp. 1927-1934, 2011.

[8] S. G. Schrank, J. N. R. D. Santos, D. S. Souza, and E. E. S. Souza, "Decolourisation effects of Vat Green 01 textile dye and textile wastewater using $\mathrm{H}_{2} \mathrm{O}_{2}$ /UV process," Journal of Photochemistry and Photobiology A: Chemistry, vol. 186, no. 2-3, pp. 125-129, 2007.

[9] R. F. P. Nogueira and W. F. Jardim, "A fotocatálise heterogênea e sua aplicação ambiental (The heterogeneous photocatalysis and its environmental application)," Química Nova, vol. 21, no. 1, pp. 69-72, 1998.

[10] M. S. Lucas, A. A. Dias, A. Sampaio, C. Amaral, and J. A. Peres, "Degradation of a textile reactive Azo dye by a combined chemical-biological process: fenton's reagent-yeast," Water Research, vol. 41, no. 5, pp. 1103-1109, 2007.

[11] S. Harimurti, A. U. Rahmah, A. A. Omar, and T. Murugesan, "Kinetics of Methyldiethanolamine mineralization by using $\mathrm{UV} / \mathrm{H}_{2} \mathrm{O}_{2}$ process," CLEAN-Soil, Air, Water, vol. 41, no. 12, pp. 1165-1174, 2013.

[12] I. T. Peternel, N. Koprivanac, A. M. L. Božić, and H. M. Kušić, "Comparative study of $\mathrm{UV} / \mathrm{TiO}_{2}, \mathrm{UV} / \mathrm{ZnO}$ and photo-Fenton processes for the organic reactive dye degradation in aqueous solution," Journal of Hazardous Materials, vol. 148, no. 1-2, pp. 477-484, 2007.

[13] A. Aleboyeh, M. B. Kasiri, M. E. Olya, and H. Aleboyeh, "Prediction of azo dye decolorization by $\mathrm{UV} / \mathrm{H}_{2} \mathrm{O}_{2}$ using artificial neural networks," Dyes and Pigments, vol. 77, no. 2, pp. 288-294, 2008.

[14] J. P. Ribeiro, D. S. Araújo, F. W. Sousa, N. S. M. Filho, L. M. Correia, and R. F. Nascimento, "Uso do processo $\mathrm{H}_{2} \mathrm{O}_{2} / \mathrm{UV}-$ adsorção no tratamento de efluente têxtil," Revista DAE, no. 183, pp. 4-8, 2010.

[15] A. G. Oliveira, J. P. Ribeiro, J. T. Oliveira, D. de Keukeleire, M. S. Duarte, and R. F. Nascimento, "Degradation of the pesticide chlorpyrifos in aqueous solutions with $\mathrm{UV} / \mathrm{H}_{2} \mathrm{O}_{2}$ : optimization and effect interfering anions," Journal of Advanced Oxidative Technologies, vol. 17, no. 1, pp. 133-138, 2014.

[16] B. H. J. Bielski and D. E. Cabelli, "Highlights of current research involving superoxide and perhydroxyl radicals in aqueous solutions," International Journal of Radiation Biology, vol. 59, no. 2, pp. 291-319, 1991.

[17] I. Talinli and G. K. Anderson, "Interference of hydrogen peroxide on the standard COD test," Water Research, vol. 26, no. 1, pp. 107-110, 1992.

[18] S. H. Lin and C. C. Lo, "Fenton process for treatment of desizing wastewater," Water Research, vol. 31, no. 8, pp. 2050-2056, 1997.

[19] M.-W. Chang, C.-C. Chung, J.-M. Chern, and T.-S. Chen, "Dye decomposition kinetics by $\mathrm{UV} / \mathrm{H}_{2} \mathrm{O}_{2}$ : initial rate analysis by effective kinetic modelling methodology," Chemical Engineering Science, vol. 65, no. 1, pp. 135-140, 2010.

[20] T. M. Elmorsi, Y. M. Riyad, Z. H. Mohamed, and H. M. H. Abd El Bary, "Decolorization of Mordant red 73 azo dye in water using $\mathrm{H}_{2} \mathrm{O}_{2} / \mathrm{UV}$ and photo-Fenton treatment," Journal of Hazardous Materials, vol. 174, no. 1-3, pp. 352-358, 2010.

[21] N. M. Mahmoodi, M. Arami, and N. Y. Limaee, "Photocatalytic degradation of triazinic ring-containing azo dye (Reactive Red 198) by using immobilized $\mathrm{TiO}_{2}$ photoreactor: Bench scale study," Journal of Hazardous Materials, vol. 133, no. 1-3, pp. 113118, 2006.

[22] E. Kowalska, M. Janczarek, J. Hupka, and M. Grynkiewicz, " $\mathrm{H}_{2} \mathrm{O}_{2} / \mathrm{UV}$ enhanced degradation of pesticides in wastewater," Water Science and Technology, vol. 49, no. 4, pp. 261-266, 2004.

[23] U. Kalsoom, S. S. Ashraf, M. A. Meetani, M. A. Rauf, and H. N. Bhatti, "Degradation and kinetics of $\mathrm{H}_{2} \mathrm{O}_{2}$ assisted photochemical oxidation of Remazol Turquoise Blue," Chemical Engineering Journal, vol. 200-202, pp. 373-379, 2012. 
[24] C. Galindo and A. Kalt, "UV- $\mathrm{H}_{2} \mathrm{O}_{2}$ oxidation of monoazo dyes in aqueous media: a kinetic study," Dyes and Pigments, vol. 40, no. 1, pp. 27-35, 1999.

[25] O. Legrini, E. Oliveros, and A. M. Braun, "Photochemical processes for water treatment," Chemical Reviews, vol. 93, no. 2, pp. 671-698, 1993. 

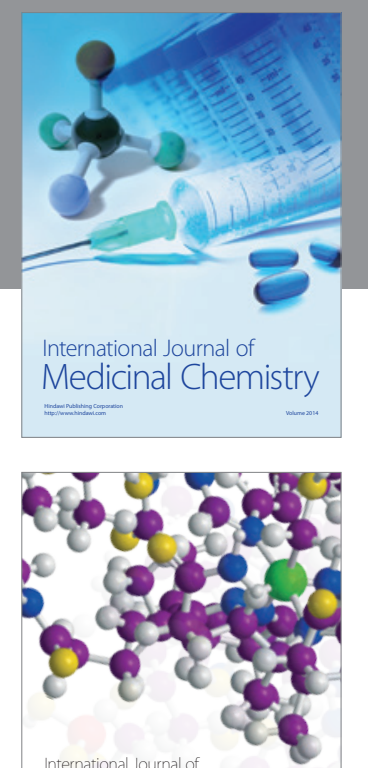

\section{Carbohydrate} Chemistry

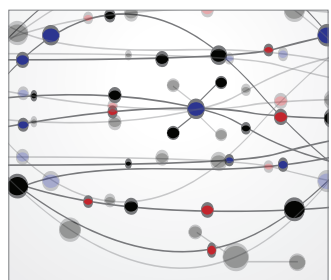

The Scientific World Journal
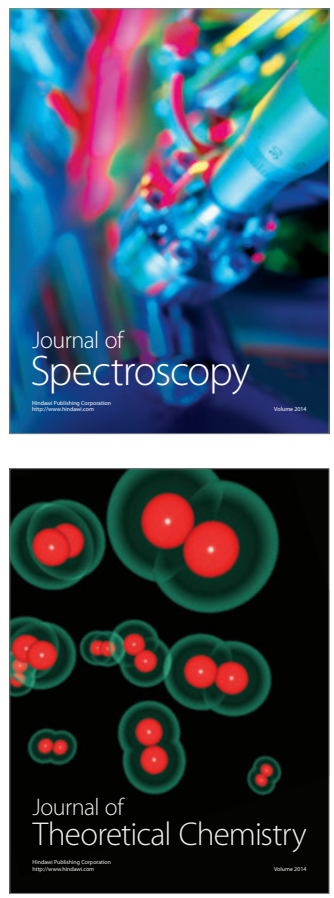
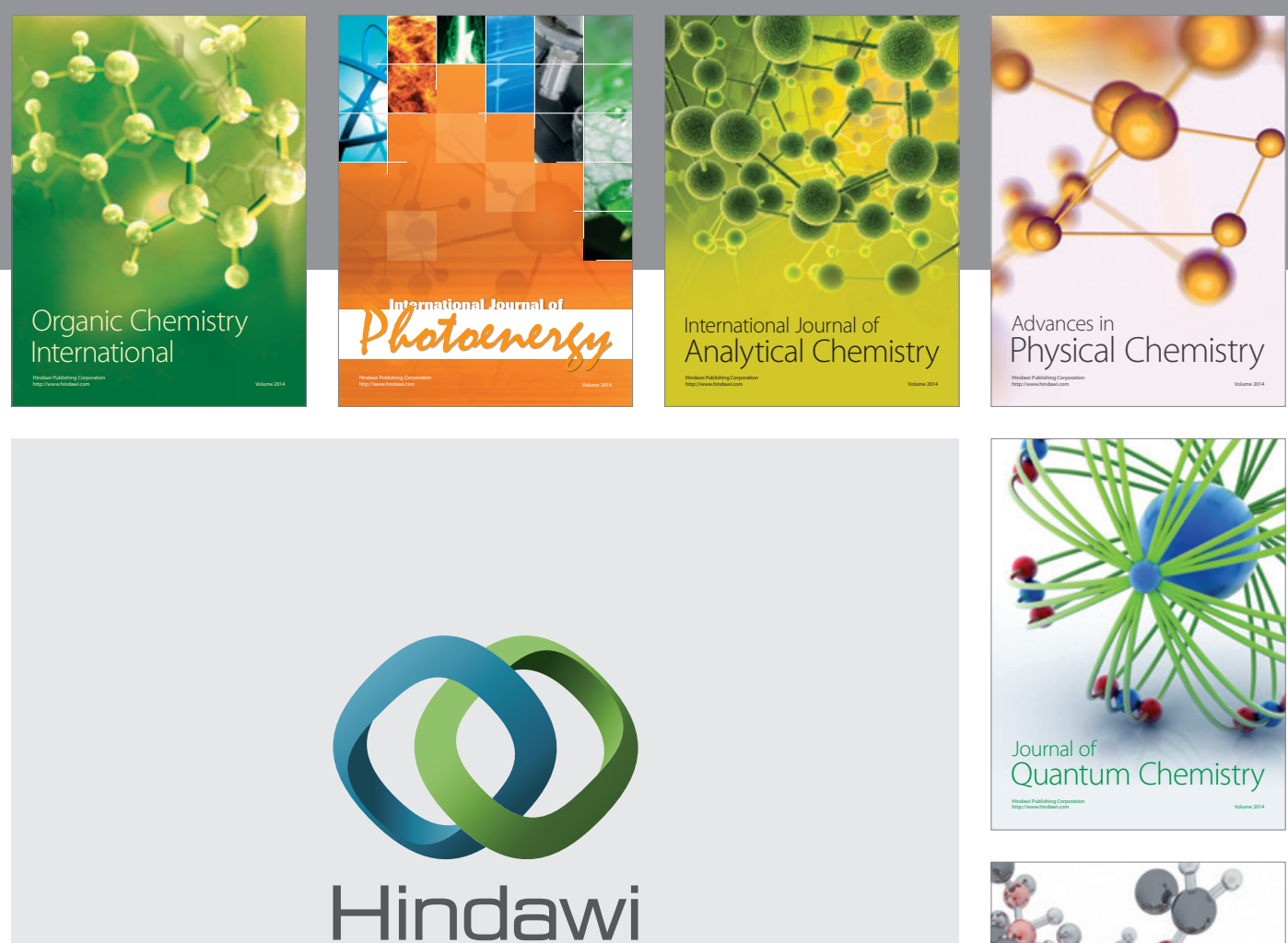

Submit your manuscripts at

http://www.hindawi.com

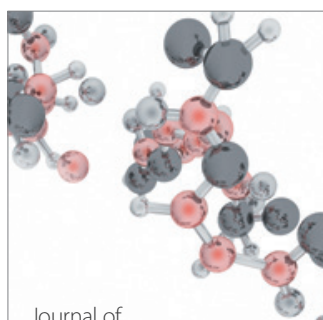

Analytical Methods

in Chemistry

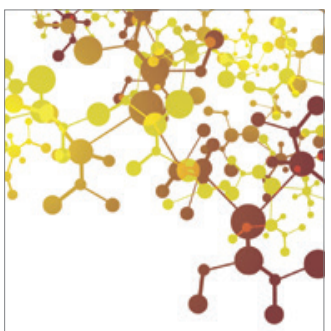

Journal of

Applied Chemistry

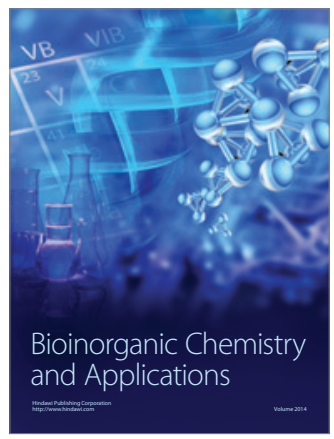

Inorganic Chemistry
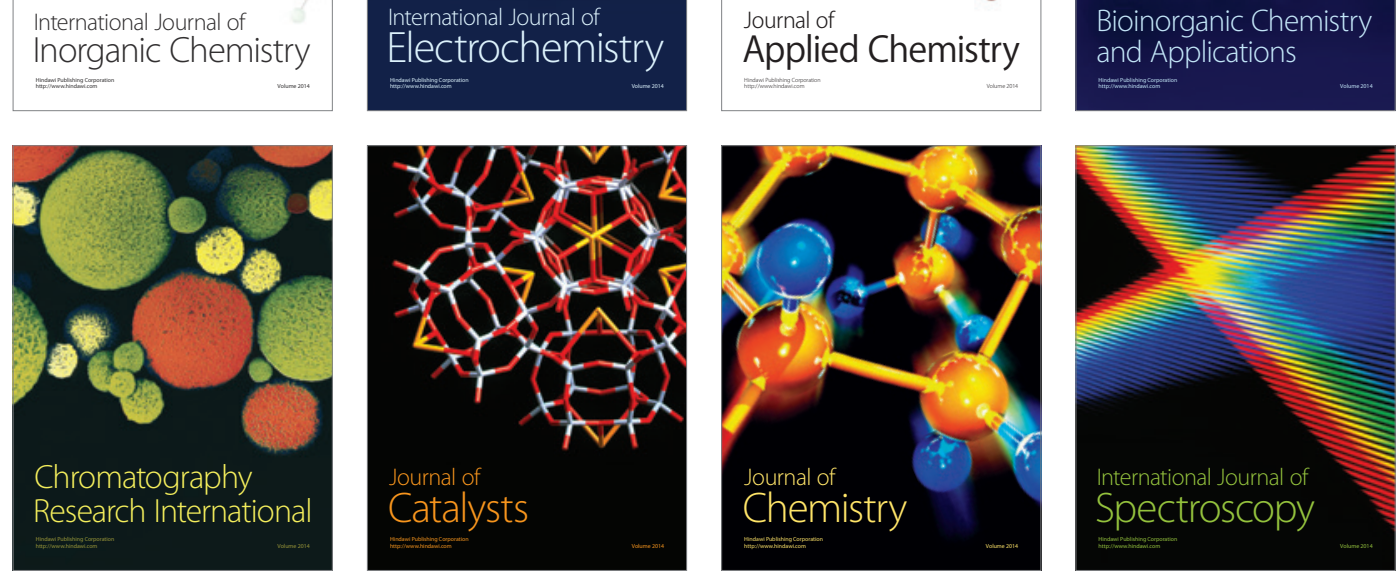